\title{
BIG FIVE PERSONALITY DAN MOTIVASI BELAJAR MAHASISWA AKADEMI KEPERAWATAN KALTARA
}

\author{
Supian $^{1}$, Siti Rahmi ${ }^{2}$, Riski Sovayunanto ${ }^{3}$ \\ Bimbingan dan Konseling, Fakultas Keguruan dan Ilmu Pendidikan Universitas Borneo \\ Tarakan \\ Email: supianubt@gmail.com
}

\begin{abstract}
Abstrak
Motivasi belajar dipengaruhi oleh berbagai faktor yang ada dalam diri mahasiswa maupun di luar diri mahasiswa. Tujuan penelitian ini adalah untuk mengetahui pengaruh big five personalty terhadap motivasi belajar mahasiswa akademi keperawatan Kalimantan Utara. Jenis penelitian ini adalah kuantitatif, dengan pendekatan survey, populasi penelitian ini sebanyak 88 mahasiswa dan sampel 43. Analisis data menggunakan statistik deskriptif dan inferensial dengan bantuan SPSS 24 for windows. Berdasarkan hasil analisis regresi uji $t$, dimana nilai $t$ hitung keseluruhan variabel independen lebih besar dari nilai t tabel (2,015) dan nilai signifikansi seluruh variabel independen lebih kecil dari (0,05). Maka ada pengaruh openness to experience, conscientiousness, extraversion, dan neuroticism yang signifikan pada motivasi belajar, dan tetapi tidak ada pengaruh agreeableness pada mahasiswa akademi keperawatan Kalimantan Utara.
\end{abstract}

Kata Kunci : Big Five Personality, Motivasi Belajar

\section{PENDAHULUAN}

Belajar merupakan suatu proses yang kompleks, karena dipengaruhi oleh banyak hal. Hal-hal yang mempengaruhi tersebut harus diperhatikan. Apabila hal-hal yang memengaruhi tidak diperhatikan dan dipelajari dengan baik, maka akan mengakibatkan mahasiswa mengalami kesulitan dalam belajarnya. Semua kesulitan- kesulitan yang dialami mahasiswa akan menyebabkan kegagalan dalam tujuan belajarnya. Salah satu kunci untuk membangkitkan prestasi belajar mahasiswa yaitu memiliki motivasi belajar yang tinggi.

Motivasi dapat diartikan sebagai daya penggerak yang telah menjadi aktif. Motif menjadi aktif pada saatsaat tertentu, terutama bila kebutuhan untuk mencapai tujuan sangat mendesak atau dirasakan, Sardiman (2016). Motivasi adalah sesuatu yang menggerakkan seseorang atau kelompok orang untuk melakukan atau tidak melakukan sesuatu, Rianto (2005). Motivasi merupakan kekuatan yang menggerakkan dan mendorong aktivitas seseorang dan membimbing kearah tujuan-tujuan. Sedangkan 
tujuan-tujuan tersebut dalam hal ini merupakan apa yang terdapat pada lingkungan yang mengelilingi seseorang yang pencapaiannya membawa kepada pemuasan motivasi tersebut, Ramayulis (2013).

Motivasi belajar dipengaruhi oleh berbagai faktor yang ada dalam diri mahasiswa maupun di luar diri mahasiswa. Salah satu yang terkait dengan motivasi belajar mahasiswa adalah kepribadian mahasiswa itu sendiri. Di perguruan tinggi mahasiswa dituntut untuk lebih rajin dan bisa memanfaatkan sumbersumber belajar yang tersedia seperti perpustakaan, laboratorium, studi lapangan, diskusi dan seminar. Mahasiswa tidak hanya tergantung pada sajian pelajaran diruang kuliah melainkan harus digali dan dipelajari dari berbagai sumber yang ada sehingga mereka dapat bersikap obyektif, berfikir logis, kritis, sistematis dan kontruktif.

Menurut Djamarah, 2015, motivasi adalah perubahan energy dalam diri seseorang yang ditandai dengan munculnya rasa (feeling) dan didahului dengan tanggapan terhadap adanya tujuan. 3 (tiga) elemen penting dalam motivasi, yaitu: 1) Perubahan Energi; motivasi terjadi karena adanya perubahan energy pada setiap individu manusia. Perkembangan motivasi akan membawa beberapa perubahan energy di dalam sistem neurophysiological yang ada pada organisme manusia; 2) Rasa; motivasi ditandai dengan munculnya rasa dan afeksi seseorang. Dalam hal ini motivasi relevan dengan persoalan- persoalan kejiwaan, afeksi dan emosi yang dapat menentukan tingkah laku manusia; 3) Tujuan; motivasi akan dirangsang karena adanya tujuan. Motivasi muncul dalam diri manusia, tetapi kemunculannya karena adanya dorongan/rangsangan oleh faktor lain.

Berdasarkan beberapa penjelasan diatas, maka dapat disimpulkan bahwa motivasi merupakan kekuatan yang menjadi daya penggerak bagi perubahan seseorang. Kekuatan tersebut menciptakan serangkaian usaha atau upaya tertentu yang berproses memberikan arah dan mengantarkan seseorang untuk bertindak demi tercapaianya tujuan hidup. Motivasi merupakan suatu perubahan energy di dalam diri pribadi seseorang yang ditandai dengan timbulnya aktif (perasaan) dan reaksi untuk mencapai tujuan.

Kepribadian merupakan aspek yang sangat penting sebagai prediktor dalam motivasi belajar. Pertama, terdapat kecendrungan berperilaku yang tercermin dalam kepribadian yang dapat mempengaruhi kebiasaankebiasaan tertentu ysng terkait dengan motivasi akademik seperti ketekunan, kesadaran, kecendrungan senang berbicara. Kedua, ketika kemampuan kognitif merujuk pada apa yang dilakukan oleh siswa maka kepribadian akan merujuk pada apa yang akan dilakukan mahasiswa tersebut. Ketiga, kepribadian sebagaimana kemampuan kognitif, akan dapat memprediksi pencapaian yang lebih baik pada mahasiswa secara khusus kepribadian berkaitan dengan motivasi belajar. Maka dapat disimpulkan bahwa 
kepribadian memberi pengaruh yang unik terhadap motivasi belajar mahasiswa.

Kepribadian (Feist \& Feist, 2008) adalah pola-pola dari sifat yang relatif permanen dan memiliki karakter unik secara konsisten dan yang ada pada akhirnya memunculkan perilkau individu. Kepribadian yang relatif menetap cenderung mendorong seseorang untuk berperilaku sesuai dengan tujuan dan tuntutan yang diberikan terhadap seseorang. (Cervone \& Pervin, 2012), membagi teori kepribadian The Five Factor Model of Personality ke dalam 5 (lima) besar faktor atau dimensi kepribadian, yaitu Neurotisisme, Ekstraversi, Keterbukaan, Kesepakatan, dan Kegigihan.

Pada penelitian Shah, dkk (2017) juga menghasilkan, bahwa agreeableness, openness, extraversion, dan Conscientiousness memberikan efek negatif pada motivasi akademik mahasiswa semester 2. Hal ini dikarenakan mahasiswa dengan kecenderungan agreeableness mengutamakan kerjasama dan ketekunan. Oleh karena itu, mahasiswa tidak pernah mengeluh maupun mengkritik apa yang diajarkan dan bagaimana hal tersebut diajarkan kepada mereka. Konsekuensinya, mereka tidak dapat tampil dalam ujian maupun mengerjakan tuga dengan persiapan yang tepat dan hal ini dapat menurunkan motivasi akademik mereka.

Terdapat pengaruh signifikan dan efek negatif dari neuroticims terhadap motivasi akademik mahasiswa semester
2. Dimana neuroticims memberikan indikasi kecemasan dan sifat implusif yang merupakan kekuatan pendorong utama yang berkontribusi terhadap penurunan dalam motiv asi akademik. Hal tersebut dikarenakan sifat cemas dan impulsif merupakan emosi yang tidak stabil dan negatif. Sebagaimana penjelasan Wagerman dan Funder dalam Shah, dkk (2017) bahwa sifat tersebut akan membuat mahasiswa dalam keadaan stres yang konstan dan konsisten, sehi ngga dapat menurunkan motivasi akademik mereka.

\section{METODE PENELITIAN}

Jenis penelitian ini adalah kuantitatif deskriptif dengan metode survey yang bertujuan untuk mengetahui big five personality dan motivasi belajar mahasiswa akademi keperawatan kaltara . Sampel dalam penelitian ini sebanyak 40 mahasiswa dari populasi 80 mahasiswa. Teknik pengumpulan data yang digunakan adalah angket dan dokumentasi. Adapun Teknik analisis data yang digunakan dalam penelitian ini adalah Analisis statistik deskriptif dan Inferensial menggunakan uji asumsi klasik yang terdapat pada beberapa uji asumsi yaitu, Uji Normalitas, uji linieritas, multikolinearitas, heteroskedastisitas dan auto korelasi. Analisis statistik Inferensial juga menggunakan Analisis regresi berganda adalah suatu metode untuk meramalkan nilai pengaruh dua variabel independen atau lebih terhadap satu variabel dependen. Lebih mudahnya yaitu untuk membuktikan ada tidaknya pengaruh antara dua variabel atau lebih dari dua 
variabel independen $\mathrm{X} 1, \mathrm{X} 2, \mathrm{X} 3, \mathrm{X} 4$, $\mathrm{X} 5$ terhadap satu variabel terikat $\mathrm{Y}$.

\section{HASIL DAN PEMBAHASAN}

\section{Hasil}

\section{Analisis Deskriptif}

Berdasarkan data diperoleh bahwa subjek yang memiliki openness to experience $(\mathrm{O})$ dalam kategori sedang lebih banyak sejumlah 46 subjek, dengan presentase $57 \%$, dibandingkan mereka yang termasuk dalam kategori tinggi sejumlah 34 subjek, dengan presentase $42,5 \%$ dan kategori rendah sejumlah 0 subjek, dengan presentase 0\%. Cervone \& Pervin (2012) menjelaskan subjek yang memiliki openness to experience yang tinggi atau sedang, memiliki sudut pandang kreatif, orisinil, imajinatif, dan memiliki rasa ingin tahu yang tinggi. Individu dengan skor openness to experience yang rendah cenderung memiliki minat yang sempit dan biasabiasa saja, sederhana, terus terang, membingungkan, lebih memilih hal yang sudah terbiasa daripada hal-hal yang baru, membumi, tidak menyukai artistik, serta tidak analitis.

Subjek yang memiliki conscientiousness (C) dalam kategori sedang lebih banyak sejumlah 57 subjek, dengan presentase $71,25 \%$, dibandingkan mereka yang termasuk dalam kategori tinggi sejumlah 23 subjek, dengan presentase 28,75\% dan kategori rendah sejumlah 0 subjek, dengan presentase $0 \%$. Cervone \& Pervin (2012) menjelaskan bahwa subjek yang memiliki conscientiousness yang tinggi dan sedang, cenderung bertanggung jawab, dapat diandalkan, menyukai keteraturan, kedisiplinan, tepat waktu, berprestasi, teliti, suka melakukan pekerjaan hingga tuntas, jenaka, menyenangkan, mereka cenderung cerdas, dipercaya, tegas, rapi, dan ambisius. Namun terlihat kaku, membosankan, perfeksionis, dan pekerja keras. Sedangkan, individu yang memiliki conscientiousness yang rendah sulit dipercaya, kurang berambisi, dan cepat menyerah. Namun mereka tidak kaku, ceroboh, tidak dapat diandalkan, dan memiliki keinginan yang lemah.

Subjek yang memiliki extraversion (E) dalam kategori sedang lebih banyak sejumlah 63 subjek, dengan presentase $78,75 \%$, dibandingkan mereka yang termasuk dalam kategori tinggi sejumlah 14 subjek, dengan persentase $17.5 \%$ dan kategori rendah sejumlah 3 subjek, dengan presentase $3,75 \%$.

Cervone \& Pervin (2012) menjelaskan bahwa subjek yang memiliki nilai extraversion yang tinggi atau sedang, cenderung aktif, gemar berorganisasi, optimis, dan penuh kasih sayang. Sedangkan, individu yang memiliki nilai extraversion rendah, cenderung kurang gembira, kurang energi, aktivitasnya rendah, cenderung lebih tenang, cenderung menarik diri dari lingkungan sosial, tertutup. Subjek yang memiliki agreeableness (A) dalam kategori tinggi lebih banyak sejumlah 73 
subjek, dengan presentase 91,25\%, dibandingkan mereka yang termasuk dalam kategori sedang sejumlah 7 subjek, dengan presentase $8,75 \%$ dan kategori rendah sejumlah 0 subjek, dengan presentase $0 \%$. Cervone \& Pervin (2012), menjelaskan bahwa subjek yang memiliki nilai agreeableness yang tinggi atau sedang, cenderung mudah bergaul dengan baik, penuh perhatian, bersahabat, derawan, dan suka menolong. Sedangkan individu yang memiliki nilai agreeableness rendah cenderung menempatkan keinginanya di atas orang lain dan tanpa kompromi, tidak memperhatikan kondisi orang lain, mudah menghadapi masalah-masalah yang menurut orang kebanyakan hanya sepele. Sedangkan, Individu yang memiliki skor neuroticism rendah cenderung tidak mudah terganggu, emosinya stabil, terbebas dari emosi negatif yang menetap, kalem, santai, tidak emosional, merasa aman.

\section{Analisis Inferensian}

Diketahui nilai korelasi ganda (R) sebesar 0,738 atau 73,8\%. Menurut Sugiyono (2014) nilai koefisien korelasi 0,60 - 0,799 artinya ada korelasi yang sifatnya kuat. Hal ini berdasarkan hasil uji $F$ bahwa Diketahui nilai $\mathrm{F}$ hitung $=17,721>$ nilai $\mathrm{F}$ tabel 2.33 dengan sig $=0,000<$ 0,05. artinya ada pengaruh yang signifikan openness to experience (X1), conscientiousness (X2), extraversion (X3), agreeableness (X4), neuroticism (X5) pada motivasi belajar mahasiswa Akademi keperawatan Kaltara.

\section{Pembahasan}

Berdasarkan hasil analisis regresi secara parsial menunjukkan dari masing- masing variabel yaitu openness to experience (O), conscientiousness $(\mathrm{C})$, extraversion $(\mathrm{E})$, agreeableness $(A)$ dan neuroticism $(\mathrm{N})$ ada pengaruh yang signifikan pada motivasi belajar mahasiswa akademi keperawatan kaltara. Hal ini dapat diketahui melalui hasil analisi $\mathrm{s}$ regresi uji $t$, dimana nilai thitung keseluruhan variabel independen lebih besar dari nilai ttabel $(2,015)$ dan nilai signifikansi seluruh variabel independen lebih kecil dari $(0,05)$. Berikut penjelasan arti dari hasil analisis regresi uji $t$ :

Openness to Experience (O) pada Motivasi Belajar. Hasil penelitian ini menemukan ada pengaruh Openness to extraperience pada motivasi belajar mahasiswa akedemi keperawatan kaltara. Hal ini disebabkan karena adanya kesamaan karakter Openness (keterbukaan) dan motivasi belajar, yaitu minat dan ketajaman perhatian dalam belajar, Prayitno, (2010). Dengan kepribadi yang memilki rasa ingin tahu yang besar, dan minat yang luas, Cervone \& Pervin, (2012). Kepribadian yang memiliki karakter yang serupa dengan motivasi belajar yang menyebabkan adanya pengaruh kepribadian terhadap motivasi belajar mahasiswa. Dengan adanya kesamaan beberapa karakter tersebut maka dapat saling mempengaruhi sehingga hasil dari penelitian ini memiliki pengaruh yang signifikan antara kepribadian openness (keterbukaan) terhadap 
motivasi belajar. kepribadian openness(keterbukaan) juga bercirikan orang yang kreatif, sejalan dengan teori Costa \& McCrae, 1985, 1992 dalam Cervone \& Pervin, 2012; Goldberg, 1981, 1992; Goldberg, 1993 dalam Irham \& Wiyani, 2013, yaitu openness to experience merupakan kepribadian yang membedakan antara orang kreatif dengan imajinatif. Dengan karakter yang kreatif pada individu dapat meciptakan ide-ide yang baru sehingga individu tidak sepenuhnya bergantung pada orang lain dalam belajarnya. Mandiri dalam belajar termasuk dalam indikator motivasi belajar, (prayitno, 2010). Penelitian ini didukung dengan teori Luthans (2011), keterbukaan terhadap pengalaman baru (openness to experience). Sifat kepribadian ini memiliki rasa ingin tahu, cerdas, kreatif. Hasil penelitian ini sejalan dengan penelitian Aisyah (2018) diperoleh nilai r2 sebesar 0,207 atau $20,7 \%$ dengan signifikan sebesar 0,000 $<0,05$ maka dapat di tarik kesimpulan openness to experience berkontribusi signifikan sebesar $20,7 \%$ pada motivasi belajar.

Conscientiousness (C) pada Motivasi Belajar. Hasil penelitian menemukan ada pengaruh Conscientiousness pada motivasi belajar mahasiswa akedemi keperawatan kaltara. Dapat diketahui Conscientiousness (kegigihan) yang pada umumya memilki kepribadian yang tegas, gigih, dan dapat diandalkan dan bertanggung jawab, (Cervone \& Pervin, 2012). Kegigihan yang dimiliki berhungan kuat dengan ketekunan dalam belajar, ulet dalam menghadapi kesulitan dihubungkan dalam hal belajar dan menjadikannya pribadi yang bisa mandiri dalam belajar, karena sikap yang bertanggung jawab dalam menyesaikan masalah sehingga dapat diandalakan Pribadi yang memiliki motivasi belajar yang tinggi. Prayitno (2010) dalam motivasi belajar bercirikan ulet dalam menghadapi kesulitan,tekun dalam belajar, dan mandiri dalam belajar,Hal ini didukung dengan penelitian sebelumnya sebagaimana hasil penelitian McCabe, dkk (2013) yakni conscientiousness memiliki hubungan yang kuat dan positif pada ketekunan belajar untuk mencapai motivasi belajar. Sehingga individu berupaya pada peningkatan kompetensi diri dengan mengembangkan keterampilan baru, menguasai situasi baru, dan belajar dari pengalaman, Dapat di ketahuai mahasiwa dengan kepribadian conscientiousness dapat mencapai motivasi belajar karena memiliki kegigihan dalam menghadapi masalahnya sendiri tanpa membutuhkan bantuan diri orang lain di sekitarnya, dan mampu bertanggung jawab menjadikannya pribadi yang dapat diandalkan untuk menyelesaikan masalah.

Extraversion

(E) pada Motivasi Belajar. Hasil penelitian menemukan ada pengaruh Extraversion pada motivasi belajar mahasiswa akedemi keperawatan kaltara. Hal ini disesbabkan Karena karakter extraversion memiliki kesamaan dengan karakter motivasi belajar, sehingga kpribadian ekstraversion yang bercirikan memiliki jiwa sosial 
yang tinggi seperti mudah berkomunikasi dengan orang banyak, aktif, dan optimis. (Cervone \& Pervin, 2012). Apabila dihubungkan pada karakter motivasi belajar dapat menggambarkan bahwa individu ini memiliki rasa ingin tahu yang tinggi karena keaktifan pada saat proses belajar dikelas, optimis yang berarti tidak mudah untuk menyerah ketika menghadapi kesulitan dalam belajar. (prayitno, 2010). Pengaruh yang signifikan pada hasil penelitian ini sejalan dengan hasil penelitian Graham dan Samuel (2013), bahwa pada mahasiswa undergraduate mempunyai extraversion yang lebih tinggi terhadap motivasi belajar. Selain itu penelitian oleh Widhiastuti (2014) memperoleh hasil, bahwa terdapat pengaruh positif dan signifikan antara faktor big five personality berupa extraversion terhadap kreativitas mahasiswa Agreeableness (A) pada Motivasi Belajar. Hasil penelitian menemukan tidak ada pengaruh agreeableness pada motivasi belajar mahasiswa akedemi keperawatan kaltara. Hal ini disebabkan pada karakter agreeableness yang memiliki skor rendah atau tidak berpengaruh berkarakter pribadi yang kasar, penuh kecurigaan, tidak pemaaf, jahat, mudah terganggu dan tidak kooperatif (Cervone \& pervin, 2012). Dari ciri-ciri yang mencerminkan karakter kepribadian agreeableness sangat mengarah kepada sikap yang negatif sehingga tidak memiliki pengaruh yang signifikan pada motivasi belajar yang dimana karakter kepribadian bercirikan penuh kecurigaan, tidak pemaaf, mudah terganggu apa bila di hubungkan dalam motivasi belajar yang tinggi akan tidak pernah sejalan dimana motivasi belajar, prayitno (2012) motivasi belajar yang tinggi bercirikan pribadi yang ulet dalam menghadapi kesulitan, minat dan ketajaman perhatian dalam belajar, dan ketekunan dalam belajar. Dalam belajar pribadi yang penuh kecurigaan besar kemungkinan tidak memiliki minat dan ketajaman perhatian karena selalu memiliki keragu-raguan, dan mudah terganggu sehingga bisa menganggu ketekunan dalam belajarnya hal ini didukung dengan penelitian sebelumnya, yang menyatakan pada penelitian Shah, dkk (2017) juga menghasilkan, bahwa agreeableness memberikan efek negatif pada motivasi akademik mahasiswa semester 2. Hal ini dikarenakan mahasiswa dengan kecenderungan agreeableness mengutamakan kerjasama dan ketekunan. Oleh karena itu, mahasiswa tidak pernah mengeluh maupun mengkritik ap a yang diajarkan dan bagaimana hal tersebut diajarkan kepada mereka. Konsekuensinya, mereka tidak dapat tampil dalam ujian maupun mengerjakan tugas dengan persiapan yang tepat dan hal ini dapat menurunkan motivasi akademik mereka.

Neuroticism (N) pada Motivasi Belajar. Hasil penelitian menemukan ada pengaruh Neuroticism pada motivasi belajar mahasiswa akedemi keperawatan kaltara. Hal ini disebabkan karena karter Neuroticism dan moivasi belajar memiliki 
kesamaan yang serupa diantaranya aspek karater Neuroticism yaitu puas dengan diri sendiri, (Cervone \& Pervin, 2012) serupa dangan motivasi belajar Prayitno (2010) mandiri dalam belajar. Hal ini dapat di gambarakan karena merasa puas terhadap diri sendiri sehingga meyakinkan untuk mandiri dalam belajar tanpa mengharapkan bantuan dari orang lain dengan keyakinan yang tinggi sehingga mendorong motivasi belajar yang tinggi dan dalam penelitian ini menghasilkan pengaruh yang signifikan pada motivasi belajar, hal ini sejalan dengan penelitian sebelumnya, Pada penelitian Shah, dkk (2017) menunjukan hasil keterkaitan antara traits kepribadian terhadap motivasi akademik, yakni terdapat pengaruh signifikan dan efek negatif dari neuroticims terhadap motivasi akademik mahasiswa semester 2 . Dimana neuroticims memberikan indikasi kecemasan dan sifat implusif yang merupakan kekuatan pendorong utama yang berkontribusi terhadap penurunan dalam motiv asi akademik. Hal tersebut dikarenakan sifat cemas dan impulsif merupakan emosi yang tidak stabil dan negatif. Sebagaimana penjelasan Wagerman dan Funder dalam Shah, dkk (2017) bahwa sifat tersebut akan membuat mahasiswa dalam keadaan stres yang konstan dan konsisten, sehi ngga dapat menurunkan motivasi akademik mereka.

\section{KESIMPULAN}

Berdasarkan temuan dalam penilitian ini yang menunjukkan adanya pengaruh antara variabel, Openness to experience $(\mathrm{O})$, Conscientiousness $(\mathrm{C})$,
Extraversion (E), Neuroticism pada motivasi belajar dan tidak adanya pengaruh variable Agreeableness (A) pada motivasi belajar.

Adapun hasil temuan dapat disimpulkan secara parsial berdasarkan hipotesis minor sebagai berikut: 1). Ada pengaruh Openness to experience pada motivasi belajar pada mahasiswa akademi keperawatan kaltara ( nilai t hitung $0,246>\mathrm{t}$ tabel 1,990 dan nilai sig $0,004<0,05$ ). 2). Ada pengaruh Conscientiousness pada motivasi belajar pada mahasiswa akademi keperawatan kaltara (nilai $\mathrm{t}$ hitung 4,260 > t tabel 1,990 dan nilai sig < 0,05). 3). Ada pengaruh Extraversion pada motivasi belajar pada mahasiswa akademi keperawatan kaltara ( niali t hitung 2,195 > t tabel 1,990 dan nilai sig $0,031<0,05$ ). 4). Tidak ada pengaruh Agreeableness pada motivasi belajar pada mahasiswa akademi keperawatan kaltara (nilai $\mathrm{t}$ hitung $-0,354<\mathrm{t}$ tabel 1,990 dan nilai sig $0,724>0,05$ ). 5). Adanya pengaruh neoroticism pada motivasi belajar pada mahasiswa akademi keperawatan kaltara ( nilai t hitung $3,852>\mathrm{t}$ tabel 1,990 dan nilai sig $0,000<0,05)$

\section{REFERENSI}

Aqib, Zainal. 2012. Profesioanlisme Guru Dalam Mengajar. Surabaya. Insan Cendikia.

Cervone, Daniel \& Pervin, A. Lawrence. 2012. Personality: Theory and Research, Edisi 10. Jakarta. Salemba Humanika.

Djamarah, Syaiful, Bahri. 2010. Strategi Belajar Mengajar. Jakarta: Rineka Cipta. 
Djamarah, Syaiful, Bahri. 2015. Psikologi Belajar. Jakarta. Rineka Cipta.

Feist, J \& Feist, J.G. 2008. Teori Kepribadian. Edisi Keenam. Yogyakarta. Pustaka Belajar.

Feist, J \& Feist, J.G. 2009. Teori Kepribadian. Edisi Keenam. Yogyakarta. Pustaka Belajar.

Ghozali, Imam. 2011. Aplikasi Analisis Multivariate dengan Program IBM SPSS 19. Semarang: Badan Penerbit Universitas Diponegoro.

Hidayat. 2015.

Kepribadian: Teori dan Aplikasi dalam Konseling. Bogor. Ghalia Indonesia.

Khairani, Makmun. 2013. Psikologi Belajar. Yogyakarta. Aswaja Pressindo.

Nikmah, R. Raudlatun. 2018. Bimbingan dan Konseling Berbasis Evaluasi dan Supervisi: Tips Cerdas Merubah Sifat dan Kebiasaan Siswa Menjadi Berprestasi. Yogyakarta. Araska.

Ramayulis. 2013. Psikologi Agama. Jakarta. Kalam Mulia.

Rianto, Anton. 2005. Born to Win: Kunci Sukses Yang Tak Pernah Gagal. Jakarta. Gramedia Pustaka Utama.

Riduwan. 2009. Metode dan Teknik Menyusun Proposal Penelitian. Bandung: Alfabeta

Rosito. 2018. Eksplorasi Tipe Kepribadian Big Five Personality Traits dan Pengaruhnya Terhadap Prestasi Akademik. Universitas Negeri Makassar. Publikasi: Jurnal Psikologi Pendidikan
\&Konseling. ISSN:2443-2202, vol. 4.

Sugiyono. 2010. Metode Penelitian Pendidikan Pendekatan Kuantitatif, Kualitatif, dan $R \& D$. Bandung: Alfabeta

Suryabrta, Sumadi. 2011. Psikologi Pendidikan. Jakarta. PT. Raja Grafindo Persada 